\title{
生体コロイド粒子間の相互作用のモデル
}

\section{Model for the Interaction of Biocolloidal Particles}

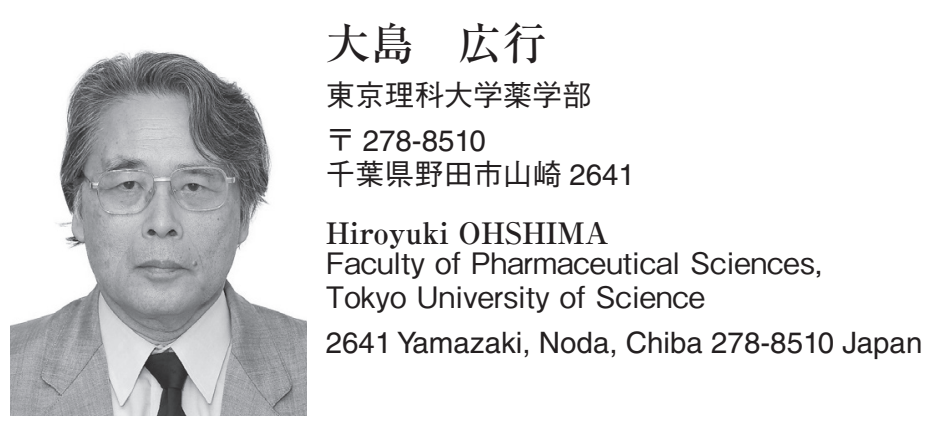

論文要旨：コロイド粒子分散系の安定性に関する Derjaguin-Landau-Verwey-Overbeek（DLVO）理論に よると, コロイド粒子間に働く van der Waals引力と静電斥力のバランスによって分散系が疑集するか分散 するかが決まる。この理論は表面構造をもたない剛体粒子を対象にしている。一方, 細胞等の生体コロイド 粒子は高分子電解質等の soft matter で覆われたいわゆる柔らかい粒子であり, 従来の DLVO 理論と異なる 新しい相互作用の理論が必要になる。本総説では, 古典的な DLVO 理論からはじめて生体コロイド粒子間 相互作用のモデルである柔らかい粒子の相互作用について述べる。

\begin{abstract}
According to the Derjaguin-Landau-Verwey-Overbeek (DLVO) theory of colloid stability, the balance of the van der Waals attraction and the electrostatic repulsion acting between colloidal particles determines the stability of their suspensions. The DLVO theory can be applied to hard particles with no surface structures. Biocolloidal particles such as cells, on the other hand, are not simple hard particles but can be modeled as soft particles, i.e., hard particles covered with a surface layer of polyelectrolytes. In this review article, we start with the traditional DLVO theory and then discuss a new theory of interactions between soft particles, which can be applied to the interaction of biocolloidal particles.
\end{abstract}

Key words: interactions, biocolloidal particles, soft particles, hard particles, DLVO theory

\section{1 はじめに：DLVO 理論}

コロイド粒子分散系の安定性に関する Derjaguin-Landau-Verwey-Overbeek（DLVO）理論 ${ }^{1-5)}$ に基づくと, 粒子間に働く van der Waals 引力と静電斥力のバランス で分散系が凝集するか分散するかを予測できる。この理 論を生体コロイド粒子に適用した先駆者の一人がCurtis である ${ }^{6)}$ 。組織中で隣り合う細胞間には $10 \mathrm{~nm}$ 程度の 間隙があるが，Curtisは DLVO 理論を適用して, van der Waals 引力と静電斥力がつりあう距離が約 $10 \mathrm{~nm}$ で あることを示した。しかし, DLVO 理論は剛体粒子を 対象にしている。一方, 細胞等の生体コロイド粒子は柔 らかい粒子 $\left.{ }^{4}, 5 ， 7-10\right)$ であり, 従来の DLVO 理論と異な る新しい相互作用の理論が必要になる。

連絡者: 大島 広行

E-mail : ohshima@rs.noda.tus.ac.jp

\section{2 コロイド粒子間の van der Waals 引カ}

コロイド粒子間には, ゆらぎ電磁場に起因する長距離 力が働く。この力は分子間に働くvan der Waals 引力に 由来する。電気的に中性で永久電気双極子モーメントを もたない分子でもゆらぎによる電気双極子モーメントを もつことができる。その結果，2 個の分子間にはゆらぎ 双極子間引力に起因する引力が働く。これが van der Waals 引力である。ゆらぎには熱的なものと絶対零度で も存在する量子力学的なものがあるが, van der Waals 引力は主として量子力学的なゆらぎによる。真空中で距 離 $r$ 離れた 2 個の異種分子 1 と 2 の間に働く van der Waals 引力相互作用のエネルギー $u(r)$ は次式で与えら れる。

$$
u(r)=-\frac{C_{12}}{r^{6}}
$$




$$
\begin{aligned}
& \text { ただし, } \\
& C_{12}=\frac{3 \alpha_{1} \alpha_{2} h}{4\left(4 \pi \varepsilon_{0}\right)^{2}}\left(\frac{2 v_{1} v_{2}}{v_{1}+v_{2}}\right)
\end{aligned}
$$

である。ここで， $\alpha_{i}$ と $v_{i}$ は分子 $i(i=1,2)$ の分極率 とゆらぎの固有振動数, $h$ はプランク定数, $\varepsilon_{0}$ は真空の 誘電率である。(2) 式右辺における $v_{1}$ と $v_{2}$ の調和平均 $2 v_{1} v_{2} /\left(v_{1}+v_{2}\right)$ を相乗平均 $\left(v_{1} v_{2}\right)^{1 / 2}$ で近似すると，(2) 式から $C_{12}=\left(C_{1} C_{2}\right)^{1 / 2}$ が得られる。ただし， $C_{1}, C_{2}$ はそ れぞれ真空中において分子 1 同士および分子 2 同士の相 互作用に関する London-van der Waals 定数である。

分子間の van der Waals 引力は短距離にしか及ばない が，共有結合と異なり飽和性を示さず相加性が比較的よ く成り立つ。このため，非常に多数の分子からできてい るコロイド粒子間には大きな van der Waals引力が働 く。したがって，真空中において，それぞれ分子密度 $N_{1}, N_{2}$ をもつ2つの粒子 1 と 2 の間の相互作用エネルギー $V$ は粒子 1 の分子と粒子 2 の分子の間の van der Waals 相互作用エネルギー $u(r)$ の総和によって与えられる。

$$
V=N_{1} N_{2} \int_{V_{1}} \int_{V_{2}} u(r) d V_{1} d V_{2}
$$

ここで, 積分は粒子 1,2 のそれぞれ体積 $V_{1}, V_{2}$ にわたっ て行なう。以下に種々の形状をもつ物体間の van der Waals 相互作用の表現を与える（Fig. 1)。

\section{$2 \cdot 12$ 枚の平行平板}

真空中において互いに距離 $h$ 離れた 2 枚の異種平行 平板 1 と 2 (それぞれ, 厚さ $d_{1}, d_{2}$, 分子密度 $N_{1}, N_{2}$, London-van der Waals 定数 $\left.C_{1}, C_{2}\right)$ の間の相互作用工 ネルギーは次式で与えられる（Fig.1（a)）。

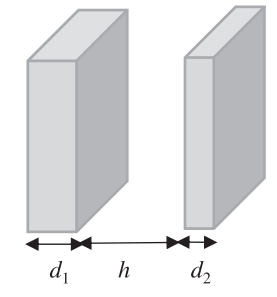

(a)

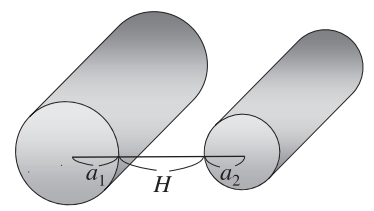

(c)

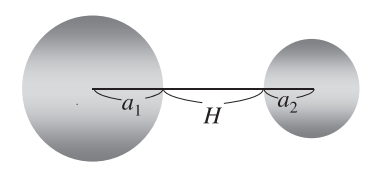

(b)

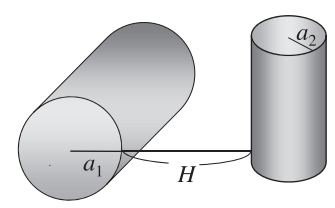

(d)
Fig. 1 Interaction between hard particles of various geometries. (a) Two parallel plates of thicknesses $d_{1}$ and $d_{2}$ at separation $h$. (b) Two spheres of radii $a_{1}$ and $a_{2}$ at separation $H$. (c) Two parallel cylinders of radii $a_{1}$ and $a_{2}$ at separation $H$. (d) Two crossed cylinders of radii $a_{1}$ and $a_{2}$ at separation $H$.

$$
V(h)=-\frac{A_{12}}{12 \pi}\left[\frac{1}{h^{2}}-\frac{1}{\left(h+d_{1}\right)^{2}}-\frac{1}{\left(h+d_{2}\right)^{2}}+\frac{1}{\left(h+d_{1}+d_{2}\right)^{2}}\right]
$$

(単位面積当たり)

ここで, $A_{12}=\pi^{2} C_{12} N_{1} N_{2}=\pi^{2}\left(C_{1} C_{2}\right)^{1 / 2} N_{1} N_{2}=\left(A_{1} A_{2}\right)^{1 / 2}$ は異種の物質 1 と 2 からなる粒子間 1 と 2 の相互作用に 対するHamaker 定数と呼ばれる。また, $A_{1}=\pi^{2} C_{1} N_{1}^{2}$, $A_{2}=\pi^{2} C_{2} N_{2}^{2}$ は物質 $i(i=1,2)$ でできた同種粒子 $i$ 間 の相互作用に対する Hamaker 定数である。小さい距離 $h\left(h \ll d_{1}, d_{2}\right)$ に対しては, (4) 式は

$V(h)=-\frac{A_{12}}{12 \pi h^{2}}$ (単位面積当たり)

になる。これは, 異種の半無限平板間の相互作用エネル ギーである。

\section{2 -2 Derjaguin 近似 : 2 個の球または 2 本の円柱の相 互作用}

表面間距離 $h$ にあ 2 枚の平行な半無限平板間の相 互作用エネルギー $V_{\mathrm{pl}}(h)((5)$ 式）がわかると, 以下の Derjaguin 近似 ${ }^{11-13)}$ を用いて, 表面間の最短距離が $H$ にある半径 $a_{1}, a_{2}$ の 2 個の球（Fig. 1 (b)), 2 本の平行 円柱（Fig. 1 (c)）または交差する円柱（Fig. 1 (d)）の 間の相互作用エネルギー $V(H)$ を計算することができ る。

$$
\begin{aligned}
& V(H)=\frac{2 \pi a_{1} a_{2}}{a_{1}+a_{2}} \int_{H}^{\infty} V_{\mathrm{pl}}(h) d h \quad(2 \text { 個の球 }) \\
& V(H)=\sqrt{\frac{2 a_{1} a_{2}}{a_{1}+a_{2}}} \int_{H}^{\infty} V_{\mathrm{pl}}(h) \frac{d h}{\sqrt{h-H}}
\end{aligned}
$$

( 2 本の平行円柱, 単位長さ当たり)

$$
V(H)=2 \pi \sqrt{a_{1} a_{2}} \int_{H}^{\infty} V_{\mathrm{pl}}(h) d h \quad(2 \text { 本の交差円柱 })
$$

これらの式は表面間距離 $H$ が小さい場合 $\left(H \ll a_{1}\right.$, $\left.a_{2}\right)$ に適用できる。(5) 式の $V(h)$ を(6)-(8) 式の $V_{\mathrm{pl}}(h)$ に代入すると以下の 3 式が得られる。

$$
\begin{aligned}
& V(H)=\frac{A_{12} a_{1} a_{2}}{6\left(a_{1}+a_{2}\right) H}(2 \text { 個の球 }) \\
& V(H)=-\frac{A_{12}}{24 H^{3 / 2}} \sqrt{\frac{2 a_{1} a_{2}}{a_{1}+a_{2}}}
\end{aligned}
$$

( 2 本の平行円柱, 単位長さ当たり)

$V(H)=-\frac{A_{12} \sqrt{a_{1} a_{2}}}{6 H} \quad(2$ 本の交差円柱 $)$

\section{$2 \cdot 32$ 個の球殼}

Derjaguin 近似（(6) 式）を用いなくても, 中心間距 離 $R=H+a_{1}+a_{2}$ にある 2 個の球 (半径 $a_{1}, a_{2}$ ) の相互作 用エネルギー $V\left(a_{1}, a_{2} ; R\right)$ の表現が以下のように求めら れる。

$$
V\left(a_{1}, a_{2} ; R\right)=-\frac{A_{12}}{6}\left\{\frac{2 a_{1} a_{2}}{R^{2}-\left(a_{1}+a_{2}\right)^{2}}+\frac{2 a_{1} a_{2}}{R^{2}-\left(a_{1}-a_{2}\right)^{2}}\right.
$$




$$
\left.+\ln \left[\frac{R^{2}-\left(a_{1}+a_{2}\right)^{2}}{R^{2}-\left(a_{1}-a_{2}\right)^{2}}\right]\right\}
$$

表面間距離 $H\left(=R-a_{1}-a_{2}\right)$ が小さい場合 $\left(H \ll a_{1}\right.$, $\left.a_{2}\right)$ ，(12）式は（9）式になる。中心間距離が $R$ 離れた 2 個の同種の球殼（半径 $a$, 厚さ $d$ ) の間の相互作用工 ネルギー $V(R)$ は次のように計算される。

$$
V(R)=V(a, a, R)-2 V(a, a-d ; R)+V(a-d, a-d ; R(13)
$$

\section{$2 \cdot 42$ 個のトーラス粒子}

赤血球の形状のモデルとしてトーラス形の粒子を考え よう ${ }^{14)}$ (Fig. 2)。円筒の両端をつなげると，トーラス粒 子になる。この円筒の半径を $a$, 円筒の中心軸からトー

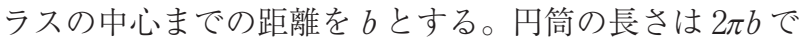
ある。トーラスは対応する半径 $a$, 長さ $2 \pi b$ の柱と等 しい表面積と体積をもつことが知られている（パップ スーギュルダンの定理)。相互作用エネルギーに関して も同様なことが成り立ち, 中心間距離が $R$ にある 2 個 のトーラス粒子の相互作用エネルギーは表面間距離 $H$ $=R-2 a$ が小さい場合 $(H \ll a), 2$ 本の平行な円柱（半 径 $a$, 長さ $2 \pi b)$ の相互作用エネルギー $V(R)$ に等しい。 すなわち

$V(R)=-\frac{A \sqrt{a}}{24 H^{3 / 2}} \times 2 \pi b$

ただし，A H Hamaker 定数である。

\section{$2 \cdot 5$ 媒質の効果}

ここまで導いてきた粒子間相互作用エネルギーの諸式

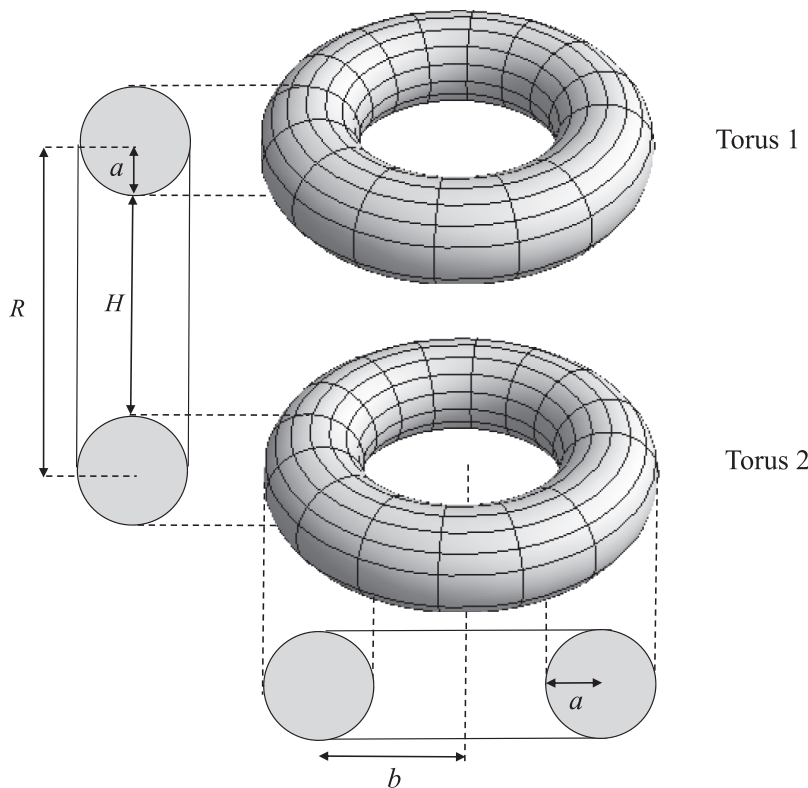

Fig. 2 Interaction between two parallel torus-shaped particles 1 and 2 at separation $R$ between their centers, where $a$ is the radius of the tube and $b$ is the distance from the center of the tube to the center of the torus.
はいずれも，真空中における粒子間相互作用である。実 際には，多くの場合，粒子は水等の媒質中にある。van der Waals 相互作用の加算性から媒質 3 中における物質 1 と 2 からなる 2 つの粒子 1,2 に対する Hamaker 定数 は次のように計算される。

$$
A_{132}=\left(\sqrt{A_{1}}-\sqrt{A_{3}}\right)\left(\sqrt{A_{2}}-\sqrt{A_{3}}\right),\left|A_{132}\right|=\sqrt{A_{131}} \sqrt{A_{232}}
$$

ここで， $A_{1}$ と $A_{2}$ はそれぞれ真空中において物質 1 か らなる粒子 1 同士および物質 2 からなる粒子 2 同士の相 互作用に関する Hamaker 定数である。とくに，媒質 3 中において物質 1 からなる同種粒子 1 同士の相互作用に 関する Hamaker 定数は次式で与えられる。

$$
A_{131}=\left(\sqrt{A_{1}}-\sqrt{A_{3}}\right)^{2}
$$

$A_{131}$ は常に正であるが, $A_{132}$ は $A_{1}, A_{2}, A_{3}$ の相対的 な大きさによって正にも負にもなる。こうして，物質 1 , 2 からなる粒子 1,2 が真空中ではなく物質 3 からなる 媒質中にあるときは，これまで導いた諸式の $A_{12}$ を $A_{132}$ で置き換える必要がある。

\section{$2 \cdot 6$ 表面層で覆われた 2 枚の平行な平板}

互いに平行な物質 1 からなる同種半無限平板が媒質 3 中においてそれぞれ物質 2 からなる表面層（厚さ $d$ ）で 覆われ表面間距離 $h$ にあるとき（Fig. 3)，相互作用エネ ルギー $V(h)$ は次のように計算される。

$$
V(h)=-\frac{1}{12 \pi}\left\{\frac{A_{232}}{h^{2}}-\frac{2 A_{123}}{(h+d)^{2}}+\frac{A_{121}}{(h+2 d)^{2}}\right\}
$$

とくに, $h$ が小さいとき, すなわち, $h$ «の場合は, （17）式は媒質 3 中において物質 2 からなる 2 枚の表面 層の間の相互作用エネルギーになる。すなわち,

$$
V(h)=-\frac{A_{232}}{12 \pi h^{2}}
$$

逆に $h » d$ の場合は, (17) 式は媒質 3 中において物

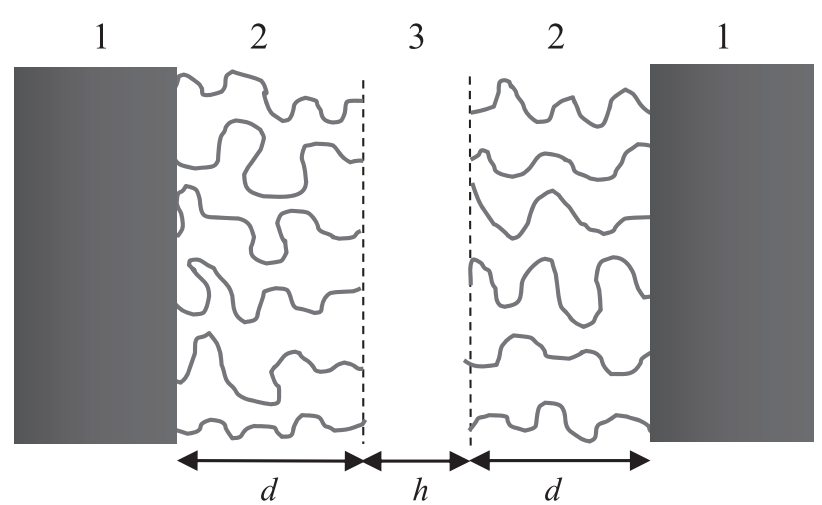

Core Surface layer Surface layer Core

Fig. 3 Interaction between two parallel plates 1 covered with surface layers 2 of thickness $d$ at separation $h$ in a medium 3 . 
質 1 からなる 2 枚の平行平板間の相互作用エネルギーに 近づく。すなわち,

$$
V(h)=-\frac{A_{232}-2 A_{123}+A_{131}}{12 \pi h^{2}}=-\frac{A_{131}}{12 \pi h^{2}}
$$

\section{3 コロイド粒子間の静電斥力}

電解質溶液中において帯電粒子の周囲には拡散電気二 重層が形成される。2 個の带電粒子が接近するとそれぞ れの粒子周囲の電気二重層が重なり粒子間の領域の対イ オン濃度が上昇するために過剰浸透圧による静電斥力が 発生する（Fig. 4）。この静電斥力を計算するためには, 相互作用する粒子周囲の電位分布を知る必要がある。

\section{$3 ・ 1$ 帯電した剛体表面近傍の電位分布}

電解質溶液中にある平板状の粒子を考えよう（Fig. 5 (a))。電解質は価数が $z$ でバルク濃度 (数密度) が $n$

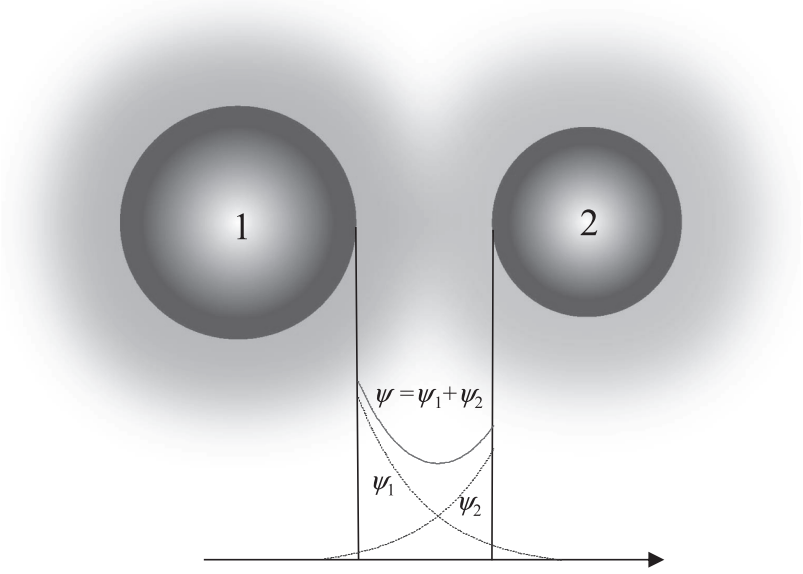

Fig. 4 Overlapping of the electrical double layers and electrical potentials $\psi$ around two particles 1 and 2 in an electrolyte solution.

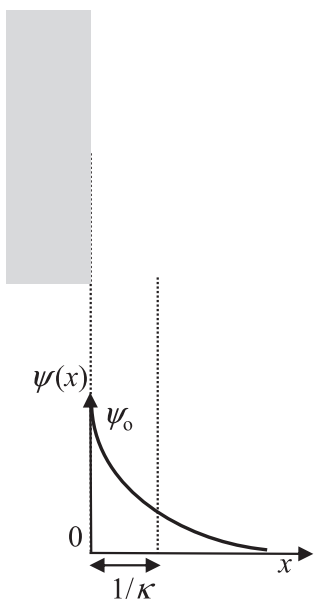

(a)

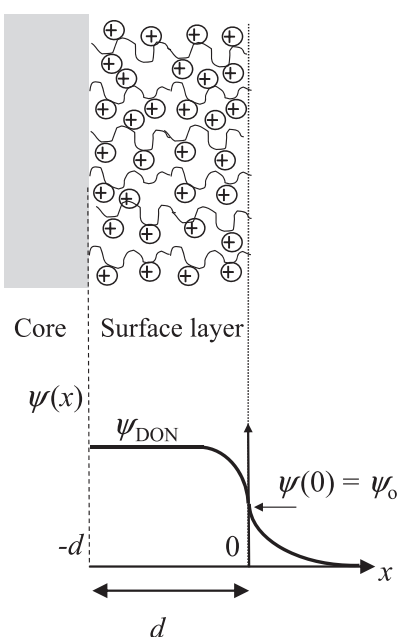

(b)
Fig. 5 Electrical potential distribution $\psi(x)$ around a hard plate (a) and a soft plate covered with a surface layer of thickness $d$ (b).
の対称型とする。はじめに，剛体粒子を扱う。粒子表面 に垂直に $x$ 軸をとり，表面を原点にとる。領域 $x>0$ が 電解質溶液に対応する。拡散電気二重層を横切る電位分 布 $\psi(x)$ は以下の Poisson-Boltzmann 方程式を解いて求 められる。

$$
\frac{d^{2} \psi}{d x^{2}}=\frac{z e n}{\varepsilon_{\mathrm{r}} \varepsilon_{0}}\left[\exp \left(\frac{z e \psi}{k T}\right)-\exp \left(-\frac{z e \psi}{k T}\right)\right], x>0(20)
$$

ここで， $\varepsilon_{\mathrm{r}}$ は電解質溶液の比誘電率， $e, k, T$ はそれ ぞれ素電荷，Boltzmann 定数，絶対温度である。(22) 式の解は次のように得られる。

$$
\psi(x)=\frac{2 k T}{z e} \ln \left(\frac{1+\gamma e^{-\kappa x}}{1-\gamma e^{-\kappa x}}\right)
$$

ただし， $\left.\gamma=\tanh \psi_{0} / 4 k T\right)$ である。また， Hückel のパラメタであり, 次式で与えられる。

$$
\kappa=\left(\frac{2 n z^{2} e^{2}}{\varepsilon_{\mathrm{r}} \varepsilon_{0} k T}\right)^{1 / 2}
$$

$\kappa$ の逆数 $1 / \kappa$ は拡散電気二重層の厚さあるいは Debye 長と呼ばれる。 $\psi_{0}$ は粒子の表面電位であり, 表面電荷 密度 $\sigma$ と次式で結ばれる。

$$
\psi_{\mathrm{o}}=\frac{2 k T}{z e} \ln \left[\frac{z e \sigma}{2 \varepsilon_{\mathrm{r}} \varepsilon_{0} \kappa k T}+\left\{\left(\frac{z e \sigma}{2 \varepsilon_{\mathrm{r}} \varepsilon_{\mathrm{o}} \kappa k T}\right)^{2}+1\right\}\right]
$$

\section{$3 \cdot 2$ 柔らかい表面近傍の電位分布}

次に，柔らかい粒子を考える（Fig. 5 (b))。粒子は高 分子電解質からなる厚さ $d$ の表面層で覆われ, この表 面層内に電解質イオンが浸入できるものとする。表面層 に垂直に $x$ 軸をとり, 表面層と周囲の電解質溶液の境界 面の位置を原点にとる。領域 $x>0$ が表面層の外部に, $-d<x<0$ が表面層内部に対応する。表面層内に洒数 $Z$ の解離基が数密度 $N$ で一様に分布している場合を考え る。電位分布 $\psi(x)$ は以下の Poisson-Boltzmann 方程式 を解いて求められる。表面層外部 $(x>0)$ に対しては $(20)$ 式が適用されるが, 表面層内部 $(-d<x<0)$ に対しては, 表面層内の固定電荷 $Z e N$ の寄与が考慮した次式が適用 される。

$$
\begin{aligned}
& \frac{d^{2} \psi}{d x^{2}}=\frac{z e n}{\varepsilon_{\mathrm{r}} \varepsilon_{\mathrm{o}}}\left[\exp \left(\frac{z e \psi}{k T}\right)-\exp \left(-\frac{z e \psi}{k T}\right)\right]-\frac{Z e N}{\varepsilon_{\mathrm{r}} \varepsilon_{\mathrm{o}}}, \\
& -d<x<0
\end{aligned}
$$

（20）式と（24）式を連立させて解くと, 表面層を横切

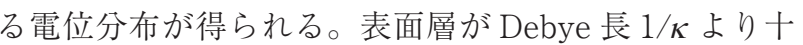
分厚い場合，表面層の奥深い部分の電位は次式で与えら れるDonnan 電位（ $\psi_{\text {DON }}$ と表す）に等しくなることが わかる。

$$
\psi_{\mathrm{DON}}=\frac{k T}{z e} \ln \left[\left(\frac{Z N}{2 z n}+\sqrt{\left.\frac{Z N}{2 z n}\right)^{2}+1}\right]\right.
$$

表面層がDebye 長より十分厚い場合は，粒子コア表 面が带電していてもその影響は小さい。また，表面層は 
一定の厚さをもつ階段関数状であるが，電位分布はイオ ンの熱運動のために階段関数的でなく指数関数的な変化 を示す。このとき表面層の先端 $(x=0)$ の電位を柔らか い粒子の表面電位 $\psi$ 。 という。 $\psi_{0}$ は次式で与えられる。

$$
\begin{aligned}
\psi_{\mathrm{o}}= & \left(\frac{k T}{z e}\right)\left(\ln \left[\frac{Z N}{2 z n}+\left\{\left(\frac{Z N}{2 z n}\right)^{2}+1\right\}^{1 / 2}\right]+\right. \\
& \left.\frac{2 z n}{Z N}\left[1-\left\{\left(\frac{Z N}{2 z n}\right)^{2}+1\right\}^{1 / 2}\right]\right)
\end{aligned}
$$

さらに，表面層内の電位分布は近似的に次式で与えら れる。

$$
\begin{aligned}
& \psi(x)=\psi_{\mathrm{DON}}+\left(\psi_{\mathrm{o}}-\psi_{\mathrm{DON}}\right) e^{\kappa_{m} x} \\
& \text { ここで, } \\
& \kappa_{\mathrm{m}}=\kappa\left[1+\left(\frac{Z N}{2 z n}\right)^{2}\right]^{1 / 4}
\end{aligned}
$$

は表面層内の Debye-Hückel のパラメタと解釈できる。 表面層の外部における $\psi(x)$ は剛体表面の場合と同じく， (21) 式で与えられる。ただし, 表面電位 $\psi_{0}$ の表現は (23) 式ではなく，(26）式で与えられる。剛体表面の場合, $\psi_{\mathrm{o}}$ が表面電荷密度 $\sigma$ で与えられる（(23）式）のに対し, 柔らかい表面では体積密度 $N$ で与えられる（(26）式）。

\section{$3 \cdot 3$ 有効表面電位}

(21) 式が示すように, 電位 $\psi(x)$ は平板からの距離 $x$ とともに指数関数的に減衰する。 $x$ が大きいとき $\psi(x)$ を次の形に表すことができる。

$\psi(x)=\psi_{\mathrm{effi}} e^{-\kappa x}$

ここで， $\psi_{\mathrm{eff}}$ を有効表面電位とよぶ。(21) 式より有効 表面電位 $\psi_{\mathrm{eff}}$ は次のように与えられることがわかる。

$$
\psi_{\text {eff }}=\frac{4 k T}{z e} \gamma=\frac{4 k T}{z e} \tanh \left(\frac{z e \psi_{0}}{4 k T}\right)
$$

電位が低い場合は, 有効表面電位 $\psi_{\text {eff }}$ は実際の表面電 位 $\psi_{0}$ に一致する。有効表面電位はコロイド粒子間の静 電相互作用エネルギーの表式（後出の（36）-(38）式） に登場する。

\section{$3 \cdot 4$ 線形重畳近似}

(Linear superposition approximation, LSA 近似)

剛体粒子間の静電相互作用の計算の際に，それぞれの 粒子の表面電位が粒子間距離にかかわらず一定に保たれ ると仮定するモデル（一定表面電位モデル）と表面電荷 密度が一定に保たれると仮定するモデル（一定表面電荷 密度モデル)がある。柔らかい粒子の相互作用の場合は, これら 2 つのモデルのいずれでもない Donnan 電位制御 モデルが適用される（Fig. 6)。この図では，2 枚の柔ら かい平行平板（表面層の厚さ $d$ で表面間距離が $h$ ) 間の 電位分布 $\psi(x)$ を表す。実線は $\kappa d=2, \kappa h=2$ の場合,

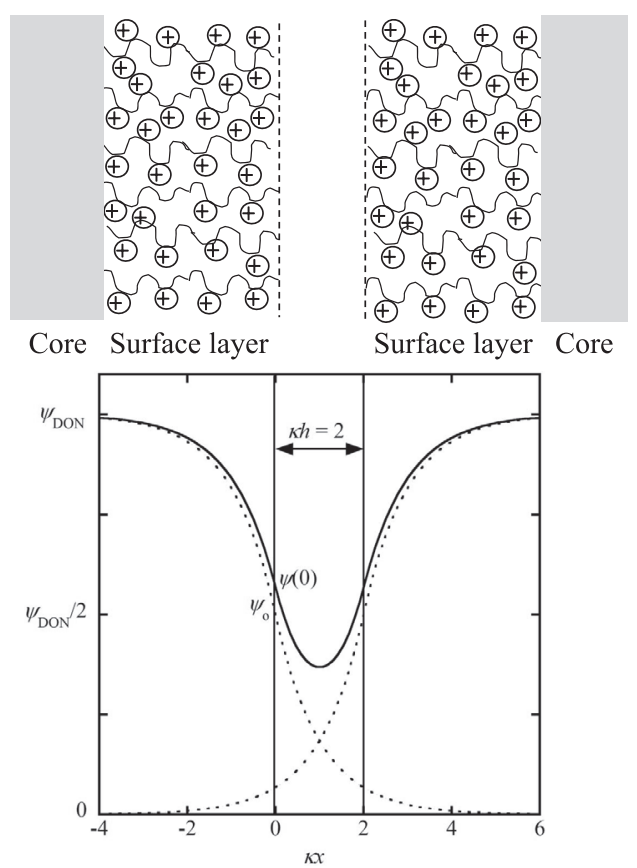

Fig. 6 Elecreoststic interaction between two parallel soft plates. The potential in the regeion deep inside the surface layers remain conatsnt at the Donnan potential $\psi_{\text {DoN }}$ during interaction. The solid line shows the potential distribution $\psi(x)$ at $\kappa h=2$ and the dotted lines represent those at $\kappa h=\infty$ (in the absence of interaction).

点線は相互作用のない場合 $(\kappa h=\infty)$ の電位分布であ る。表面層の奥深いところの電位は平板間距離に無関係 に常にDonnan 電位に保たれる。

2 個のコロイド粒子間の静電相互作用のエネルギーを 求めるには, 一般に非線形の Poisson-Boltamann 方程式 を解かなくてはならないが，これは容易ではない。しか し, 線形重畳近似 (Linear superposition approximation, LSA 近似）を用いると相互作用エネルギーを簡単 に計算できる。この近似では，2粒子の相互作用エネル ギーをそれぞれの粒子の相互作用のないときの有効表面 電位 $\psi_{\text {eff }}$ (電位が低いときは表面電位 $\psi_{0}$ に一致）を用い て表現するため，一定表面電位モデル，一定表面密度モ デル, Donnan 電位制御モデルのすべての場合にこの近 似を適用できる。

距離 $h$ にある 2 枚の平行平板間の相互作用エネルギー を計算する。平板に垂直に $x$ 軸をとり, 左側の平板 1 の 表面に原点 0 をとる。相互作用のないときの平板 1 と 2 の遠方に扮ける電位を $\psi_{1}(x), \psi_{2}(x)$ と置くと（29）式 から次式のように表される。

$$
\psi_{1}(x)=\psi_{\mathrm{eff} 1} e^{-\kappa x}, \quad \psi_{2}(x)=\psi_{\mathrm{eff} 2} e^{-\kappa(h-x)}
$$

ここで, $\psi_{\mathrm{eff} 1}$ と $\psi_{\mathrm{eff} 2}$ は平板 1 と 2 の有効表面電位であ る。平板 1 と 2 の中間近傍では電位は低く, $\psi(x)$ は近 
似的に $\psi_{1}(x)$ と $\psi_{2}(x)$ の和として次のように表される (Fig. 4 参照)

$$
\psi(x)=\psi_{1}(x)+\psi_{2}(x)=\psi_{\mathrm{eff} 1} e^{-\kappa x}+\psi_{\mathrm{eff} 2} e^{-\kappa(h-x)}
$$

平板 1 と 2 の間の相互作用力 $P(h)$ は一方の板を囲む 任意の閉曲面 $\Sigma$ 上で浸透圧と Maxwell 張力を積分して 得られる。 $\Sigma$ として平板 1 を囲む 2 枚の平面 $x=-\infty$ (バ ルク液体中） と $x=x^{\prime}\left(0<x^{\prime}<h\right)$ を考える。ここで， $x^{\prime}$ は平板間 $0<x<h$ の任意の点である。この結果，単位面 積当たりの $P(h)$ は次式で与えられる。

$$
\begin{aligned}
P(h)= & n k T\left[\exp \left(\frac{z e \psi\left(x^{\prime}\right)}{k T}\right)+\exp \left(-\frac{z e \psi\left(x^{\prime}\right)}{k T}\right)-2\right]-\frac{1}{2} \\
& \varepsilon_{\mathrm{r}} \varepsilon_{0}\left(\left.\frac{d \psi}{d x}\right|_{x=x^{\prime}}\right)^{2} \approx \frac{1}{2} \varepsilon_{\mathrm{r}} \varepsilon_{0}\left\{\kappa^{2} \psi^{2}\left(x^{\prime}\right)-\left(\left.\frac{d \psi}{d x}\right|_{x=x^{\prime}}\right)^{2}\right\}
\end{aligned}
$$

平板 1 と 2 の中間近傍では（32）式を（33）式に代入 して

$$
P(h)=2 \varepsilon_{\mathrm{r}} \varepsilon_{0} \kappa^{2} \psi_{\mathrm{eff} 1} \psi_{\mathrm{eff} 2} e^{-\kappa h} \text { (単位面積当たり) }
$$

が得られる。平板 1 と 2 の相互作用エネルギー $V(h)$ は次式で与えられる。

$V(h)=\int_{h}^{\infty} P(h) d h=2 \varepsilon_{\mathrm{r}} \varepsilon_{0} \kappa \psi_{\mathrm{eff} 1} \psi_{\mathrm{eff} 2} e^{-\kappa h}$

（単位面積当たり）

（39）式と Derjaguin 近似（(10)-(12) 式）を組み合 わせると，表面間最短距離 $H$ にある半径 $a_{1}, a_{2}$ の 2 個 の球および 2 本の円柱間の相互作用エネルギー $V(H)$ を計算することができる。結果を以下に与えた。

$$
\begin{aligned}
& V(H)=\frac{4 \pi a_{1} a_{2}}{a_{1}+a_{2}} \varepsilon_{\mathrm{r}} \varepsilon_{0} \psi_{\mathrm{eff} 1} \psi_{\mathrm{eff} 2} e^{-\kappa H} \quad(2 \text { 個の球 }) \\
& V(H)=2 \sqrt{\frac{2 \pi a_{1} a_{2}}{a_{1}+a_{2}}} \sqrt{\kappa} \varepsilon_{\mathrm{r}} \varepsilon_{0} \psi_{\mathrm{eff} 1} \psi_{\mathrm{eff} 2} e^{-\kappa h}
\end{aligned}
$$

(2 本の平行な円柱，単位長さ当たり）

$$
V(H)=4 \pi \sqrt{a_{1} a_{2}} \varepsilon_{\mathrm{r}} \varepsilon_{0} \psi_{\mathrm{eff} 1} \psi_{\mathrm{eff} 2} e^{-\kappa H}
$$

(2 本の交差する円柱)

これらの結果は柔らかい粒子（平行平板，半径 $a_{1}, a_{2}$ の球または円柱のコアが厚さ $d_{1}, d_{2}$ の表面層に覆われ ている）の相互作用にも適用できる（Fig. 7)。この場合， 表面電位の表現を（23）式から（26）式に変更し, かつ, (36)-(38) 式において， $a_{1}$ と $a_{2}$ を $b_{1}=a_{1}+d_{1}$ と $b_{2}=a_{2}+$ $d_{2}$ に置き換える。

\section{4 表面層の接触後の静電相互作用}

ここまでの議論では，2つの粒子の表面層が接触する までの静電相互作用を扱ってきた。ここでは, 対称型電 解質溶液中で（価数 $z$, 数密度 $n$ ) 2 枚の同種の柔らか

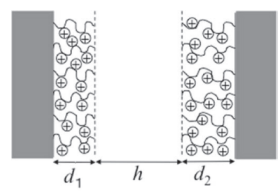

(a)

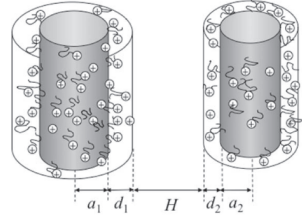

(c)

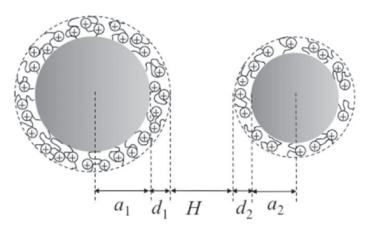

(b)
Fig. 7 Interaction between soft particles of various geometries. (a) Two parallel plates covered with surface layers of thicknesses $d_{1}$ and $d_{2}$ at separation $h$. Two spheres (b), two parallel cylinders (c), and two crossed cylinderes (d) of radii $a_{1}$ and $a_{2}$ covered with surface layers of thicknesses $d_{1}$ and $d_{2}$, respectively, at separation $H$.

い平板（高分子ブラシ層）が互いに接触した後の静電相 互作用を考えよう。2 段階モデル ${ }^{15)}$ と 3 段階モデル ${ }^{16)}$ の二つのモデルが提出されている (Fig. 8)。

\section{$4 \cdot 1$ 圧縮モデル（2 段階モデル）}

Fig. 8 (a) のように, 接触前 (第一段階) は各平板の コア上に厚さ $d_{0}$ の高分子電解質からなる表面層があり, コア面間の距離を $h$ とする。表面層内の解離基の価数 を $Z$, 数密度を $N_{0}$ とする。2つの表面層が接触すると $(h$ $\left.=2 d_{0}\right)$, 表面層内で電位は平ら（電場がゼ口）になる。 この電位は Donnan 電位に等しい。さらに距離 $h$ が減少 すると $\left(h<2 d_{0}\right)$, 表面層が圧縮されて表面層の厚さ $d(=$ $h / 2)$ は $d_{0}$ より小さくなり, 表面層内の固定電荷の密度 $N$ が上昇して Donnan 電位が増大する。ここで，2つの 表面層は互いに組み合わさらずに表面層の圧縮のみが起 きるものとする(第 2段階)。したがって, $N d=N h / 2$ $=N_{\mathrm{o}} d_{\mathrm{o}}$ が成り立つ。Donnan 電位が増大するために平板 間に静電斥力が生じる。Donnan 電位が低いときは, 静 電斥力は $1 / h^{2}$ に比例し, Donnan 電位が高いときは, 単 位面積当たりの静電斥力は $1 / h$ に比例することが示さ れる。一方 de Gennes の理論 ${ }^{17)}$ に基づいて，2枚の電 気的に中性な高分子ブラシ層が接触し表面層が圧縮され るときに生じる単位面積当たりの斥力の表現が浸透圧項 と弾性項の和の形に求められるが, 静電斥力と同程度の 大きさであることが示される。

\section{$4 \cdot 2$ 嵌合一圧縮モデル（3 段階モデル）}

このモデルでは，2段階モデルでは考慮しなかった表 面層の互いの組み合わせ (嵌合)を考慮する (Fig. 8(b))。 


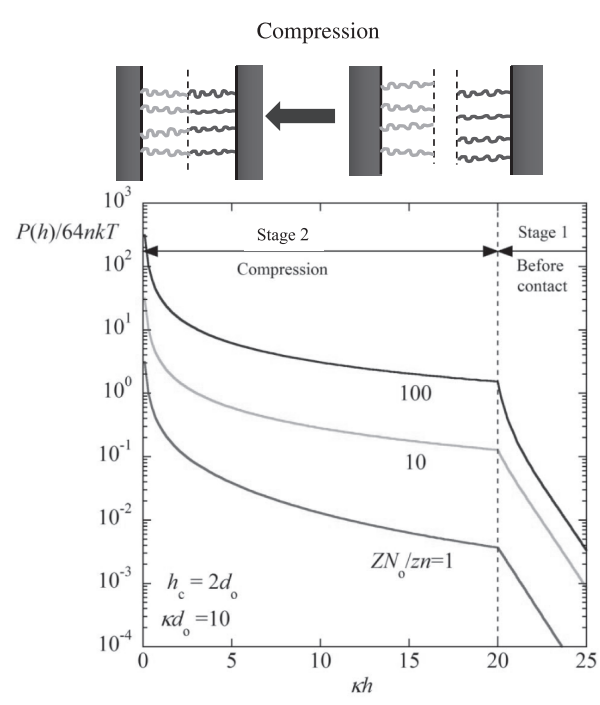

(a)
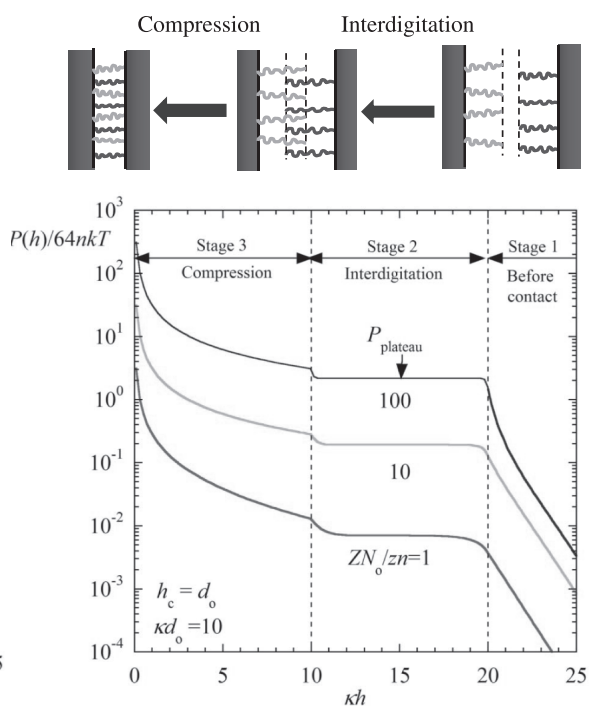

(b)

Fig. 8 A two-stage model $(a)^{15)}$ and a three-stage model $(b)^{16)}$ for the electroststic interaction between two soft plates after constact of their surface layers, where $d_{0}$ is the thickness of the intact brush layer and $N_{\mathrm{o}}$ is the density of ionized groups in the intact brush layer. The compression starts at $h=h_{c}$, where $h_{\mathrm{c}}=2 h_{\mathrm{o}}$ for the two-stage model and $h_{\mathrm{c}}=h_{\mathrm{o}}$ for the three-stage model. The scaled repulsion $P / 64 n k T$ per unit area between two parallel plates covered with a polymer brush layer is calculated as a function of scaled separation $\kappa h$ at $\kappa d_{\circ}=10$ for $Z N_{\circ} / z n=1,10$ and 100 .

すなわち，第 1 段階（接触前），第 2 段階（嵌合, interdigitation)，第 3 段階（圧縮， compression）である。 このモデルにおける 2 枚の柔らかい平板間の静電斥力 (単位面積当たり) $P(h)$ を平板コア面間の距離 $h$ の関 数として示すと, 嵌合の進行中, 相互作用力 $P(h)$ は $h$ に依存せず，ほぼ一定に保たれることがわかる。

\section{5 相互浸入相互作用}

コアをもたない 2 個の柔らかい粒子の静電相互作用に 対しては，相互浸入 (interpenetration) モデルが提出 されている $(F i g .9(a))^{18,19)}$ 。これは白血球の一種であ るマクロファージが細菌などを捕食する作用である嶺食 作用のモデルになる可能性がある。Fig. 9 (b) にはこの 相互作用の力とポテンシャルエネルギーの計算例を与え た。

\section{6 離散電荷効果}

ここまでは粒子表面の電荷が連続分布を仮定したが, 実際には電荷は離散分布をしている。2枚の平行平板 1 と 2 が距離 $h$ にあり，それぞれの平板上の表面層内にお いて, 点電荷 $q$ が単純立方格子（格子定数 $a$ ）上に分布 している場合を考えよう（Fig. 10（a））。表面層の厚さ $d$ はDebye 長に比べ十分厚いものとする。さらに, 平板 1 と 2 の表面層間のずれベクトルを $D$ とする。電位が低い 場合, 相互作用エネルギーは次式で与えられる ${ }^{20)}$

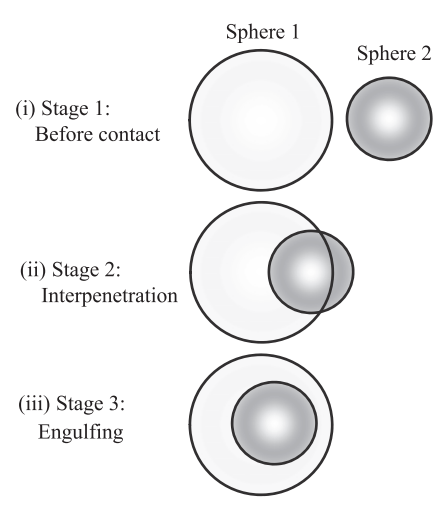

(a)
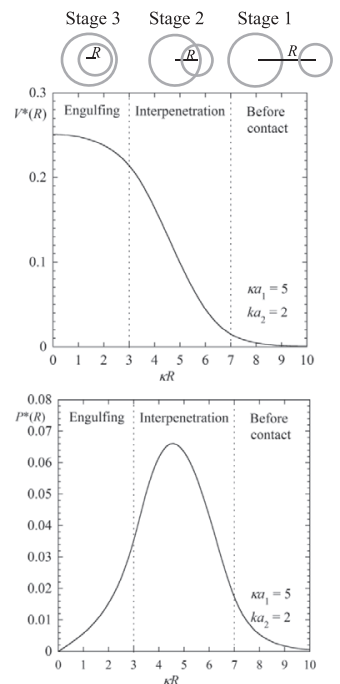

(b)

Fig. 9 A three-stage model for the electrostatic interaction between two chrged soft parrticles (porous spheres) 1 and 2. (i) Before contact, (ii) interpenetration, and (iii) engulfing $(a)^{18,19)}$. Scaled potential energy $V^{*}(R)=$ $V(R) /\left(4 \pi a_{1} a_{2} \rho_{1} \rho_{2} / \varepsilon_{\mathrm{r}} \varepsilon_{0} \kappa^{3}\right)$ and scaled force of the electrostatic interaction $P^{*}(R)=P(R) /\left(4 \pi a_{1} a_{2} \rho_{1} \rho_{2} / \varepsilon_{\mathrm{r}} \varepsilon_{0} \kappa^{2}\right)$ between two dissimilar charged soft particles with no particle core (porous spheres) 1 and 2 at separation $R$ between their centers for three stages of interaction, that is, interaction before contact, interpenetration, and engulfing. Calculated with $\kappa a_{1}=5$ and $\kappa a_{2}=2$. 


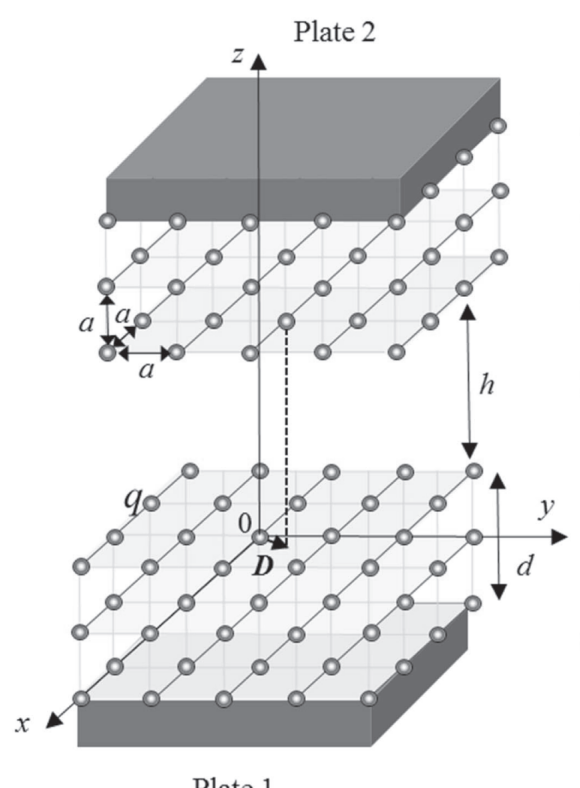

Plate 1

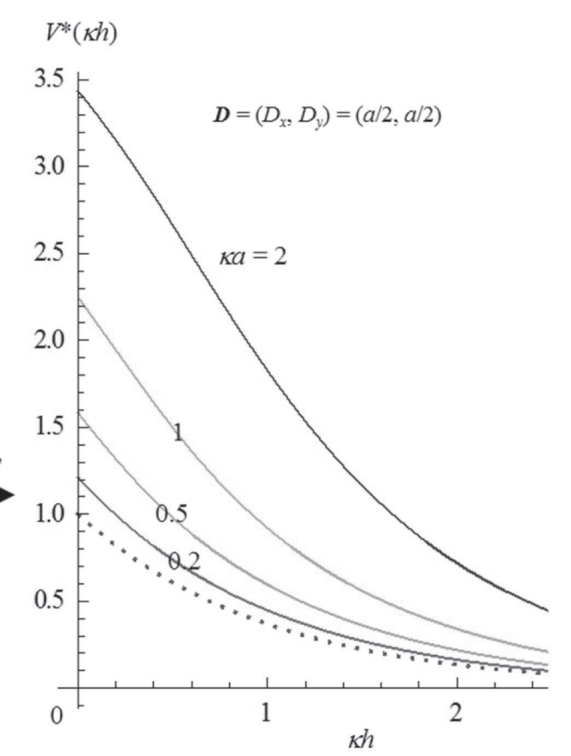

(b)

Fig. 10 (a) Two interacting soft plates 1 and 2 at separation $h$ consisting of a discrete cubic lattice of fixed point charges $q$ with a spacing of $a$ within a surface layer. (b) Scaled interaction energy $V^{*}\left(\kappa h, D_{x}, D_{y}\right) \equiv V\left(\kappa h, D_{x}, D_{y}\right) /\left(q^{2} / \varepsilon_{\mathrm{r}} \varepsilon_{0} \kappa^{3} a^{6}\right)$ between two parallel soft plates per unit area as a function of scaled plate separation $\kappa h^{20}$. Calculated for the displacement vector $D=\left(D_{x}, D_{y}\right)=(a / 2, a / 2)$ at four values of $\kappa a=2,1,0.5$, and 0.2 . The dotted line corresponds to the smeared-charge model $(\kappa a \rightarrow 0)$.

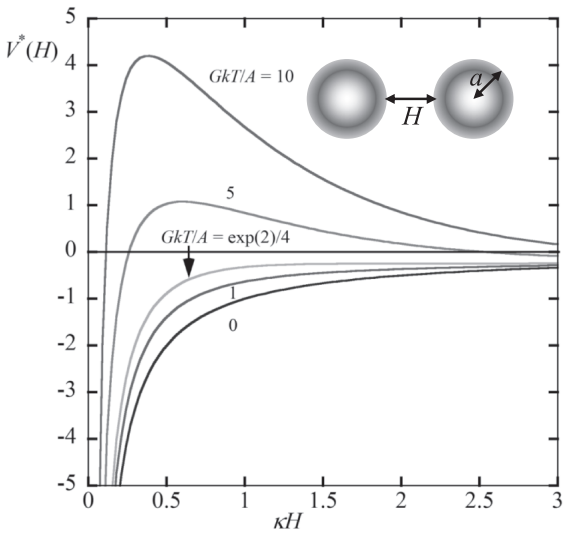

(a)

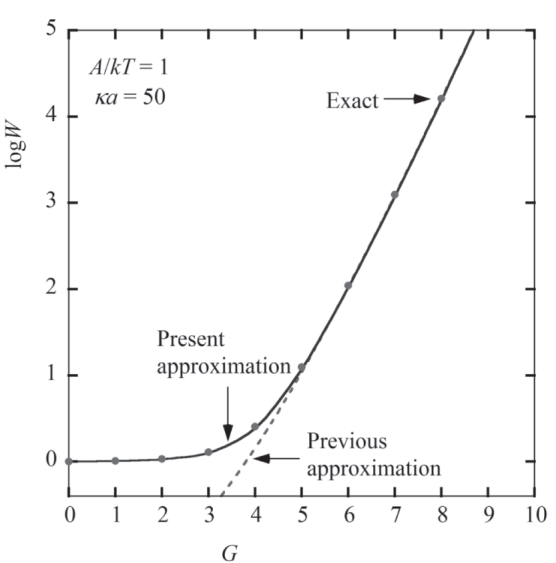

(b)

Fig. 11 (a) The scaled potential energy $V^{*}(H)=V(H) /(A \kappa a / 12 k T)$ as a function of the scaled separation $\kappa H$ for several values of $G k T / A$. The potential curve exhibits a maximum if $G k T / A>\exp (2) / 4(=1.8473)$, while there is no maximum if $0 \leq$ $G k T / A \leq \exp (2) / 4$. (b) The logarithm of the stability ratio $W$ as a function $G$ at $A / k T=1$ and $\kappa a=50$. The solid line represents the present approximate results (Eq. (43) as combined with Eq. (42)) ${ }^{21}$, which coincides with numerical results represented by filled circles within the line width. The dotted line shows the previous approximation.

$$
\begin{aligned}
& V\left(h, D_{x}, D_{y}\right)=\frac{q^{2}}{4 \pi \varepsilon_{\mathrm{r}} \varepsilon_{0} a^{2}} \sum_{\substack{-\infty<, m<\infty \\
-\infty<n \leq 0,0 \leq n<\infty}} \\
& \frac{\exp \left[-\kappa \sqrt{\left(l a-D_{x}\right)^{2}+\left(m a-D_{y}\right)^{2}+\left\{h+\left(n^{\prime}-n\right) a\right\}^{2}}\right]}{\sqrt{\left(l a-D_{x}\right)^{2}+\left(m a-D_{y}\right)^{2}+\left\{h+\left(n^{\prime}-n\right) a\right\}^{2}}}
\end{aligned}
$$

Fig. 10 (b) に計算例を与えた ${ }^{20)} 。 \kappa a \rightarrow 0$ の極限で連 続分布モデルに帰着する。

\section{7 コロイド粒子分散系の安定性の指標 : 安定度比}

DLVO 理論では，2 個のコロイド粒子間には van der
Waals 引力と静電斥力が同時に働く。価数 $z$, バルク濃 度 $n$ の対称型電解質溶液中で表面間距離 $H$ にある 2 個 の球状粒子（半径 $a$ ) を考える。粒子間に働く相互作用 のポテンシャルエネルギーを $V(H)$ とする。粒子の表 面電位が $\psi_{0}$, Hamaker 定数が $A$ の場合, $V(H)$ は粒子 間の静電斥力エネルギー $V_{\mathrm{R}}(H)$ と van der Waals 引力 エネルギー $V_{\mathrm{A}}(H)$ の和 $V(H)=V_{\mathrm{R}}(H)+V_{\mathrm{A}}(H)$ で与 えられる（(9) 式と（36）式参照）（Fig.11（a）。ただ し 


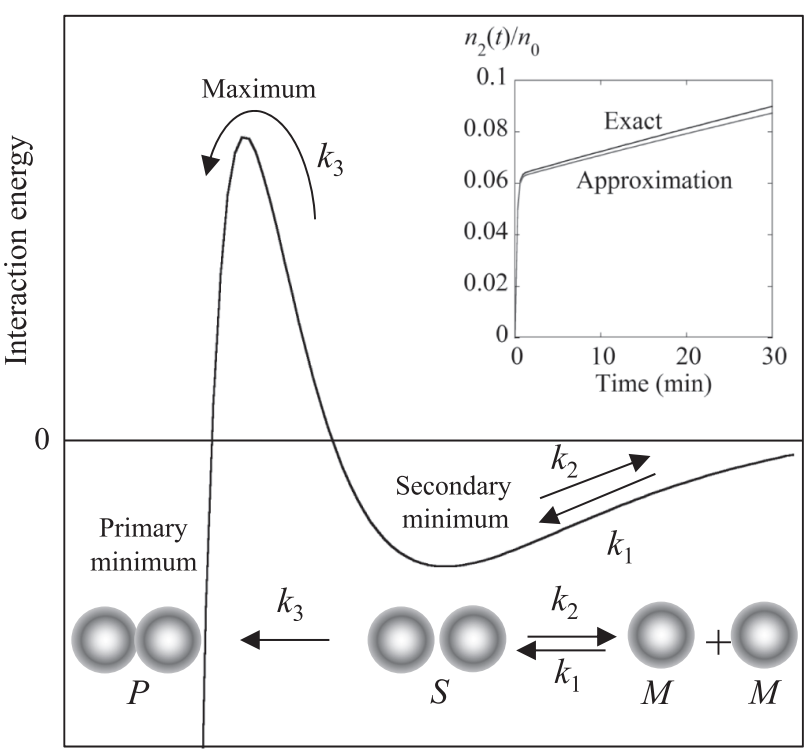

Particle separation

Fig. 12 A typical interaction energy profile leading to the association of two single-particle monomers $\mathrm{M}$ to form both irreversibly aggregated dimes P (primary aggregated dimers) and reversibly aggregated dimers S (secondary aggregated dimers) ${ }^{22)}$. The inlet shows a comparison of two results for the time evolution of the concentration $n_{2}(t)$ of the total aggregated dimers $(S+P)$, that is, the present analytic result (Eqs. (47) and (48)) and exact numerical solutions to Eqs. (45) ${ }^{23)}$. Calculated with $n_{0}=10^{15}$ $\mathrm{m}^{-3}, k_{1}=1.1 \times 10^{-17} \mathrm{~m}^{3} \mathrm{~s}^{-1}, k_{2}=6.6 \times 10^{-2} \mathrm{~s}^{-1}$, and $k_{3}=$ $3.2 \times 10^{-4} \mathrm{~s}^{-1}$.

$$
V_{\mathrm{R}}(H)=\frac{64 \pi a n k T \gamma^{2}}{\kappa^{2}} e^{-\kappa H}=\frac{G \kappa a k T}{12} e^{-\kappa H}, \quad V_{\mathrm{A}}(H)=-\frac{A a}{12 H}
$$

ここで, $\gamma=\tanh \left(z e \psi_{\mathrm{o}} / 4 k T\right)$ および $G=384 \pi \gamma^{2} \varepsilon_{\mathrm{r}} \varepsilon_{0} k T /$ $z^{2} e^{2} \kappa$ である。ポテンシャル曲線の例を Fig. 12 (a) に示 す。DLVO 理論では，2 個の粒子が互いに接触すると， $H=0$ における第一極小において不可逆的に凝集すると 仮定する。 $V_{\mathrm{R}}$ の寄与が大きいと, ポテンシャル曲線に 極大 $V_{\max }$ が現れるが，これは凝集に対する障壁の役を する。極大 $V_{\max }$ が大きいほど, 分散系の安定性が増す。 極大の存在条件は $G k T / A>\exp (2) / 4$ で与えられる。 $V_{\max }$ が熱エネルギー $k T$ に比べて十分大きい場合（ $V_{\max }$ 》15kT）はコロイド粒子は凝集せず分散系は安定と見 なされる。分散系の安定性を定量的に評価するためには 以下に述べる安定度比 $W$ が指標になる。

粒子間に van der Waals 引力相互作用 $V_{\mathrm{A}}$ のみ働く場 合の凝集速度（1秒間に 1 個の粒子が他の粒子に衝突し 凝集する回数）に比べて粒子間に静電斥力相互作用 $V_{\mathrm{R}}$ が加わる場合の凝集速度は遅くなる。この遅くなる割合 が安定度比 $W$ である。Wが大きいほど分散系の凝集速 度は遅くなり系は安定である。さらに, 接近する 2 粒子
間の粘性相互作用を表す因子 $\beta$ を考慮すると安定度比 $\mathrm{W}$ は $W=q / q^{0}$ で与えられる。ただし

$$
\begin{gathered}
q=2 \int_{0}^{\infty} \beta(u) \frac{e^{V / k T}}{(u+2)^{2}} d u, \quad q^{\circ}=2 \int_{0}^{\infty} \beta(u) \frac{e^{V_{A} / k T}}{(u+2)^{2}} d u, \\
\beta(u)=\frac{6 u^{2}+13 u+2}{6 u^{2}+4 u}=\frac{(6 u+1)(u+2)}{2 u(3 u+2)}
\end{gathered}
$$

ここで, $u=H / a$ である。さらに, $q^{0}$ は次のように計 算される。

$$
q^{\circ}=\frac{11}{8} \exp \left(\frac{A}{24 k T}\right) E_{1}\left(\frac{A}{24 k T}\right)-\frac{9}{8} \exp \left(\frac{A}{8 k T}\right) E_{1}\left(\frac{A}{8 k T}\right)
$$

ここで, $E_{1}(z)$ は指数積分である。以下の高精度の近 似式が導かれている ${ }^{21)}$

$$
W=1+\frac{1}{2 q_{\text {visc }}^{\mathrm{o}}} \sum_{m=1}^{\infty} \frac{1}{m !}\left(\frac{\kappa a G}{12}\right)^{m} K_{0}\left(\sqrt{\frac{A \kappa a m}{3 k T}}\right)
$$

ここで, $K_{n}(z)$ は $n$ 次の第 2 種変形ベッセル関数で ある。Fig. 11（b）は $\log W$ を $G$ の関数として計算した 例であるが数值解との一致は極めてよい。なお，従来の $W$ の計算では，極大のまわりで相互作用エネルギーを 展開するが, この方法はポテンシャル極大が低い場合あ るいは存在しない場合は有効でない(Fig. 11(b)の点線)。

柔らかい粒子の場合は，表面層が接触したときに（H $=0)$, 熱エネルギー $k T$ より十分深いポテンシャル極小 が存在して不可逆的な凝集が起こるときは上記の理論が そのまま適用できる（ただし，表面電位の表現を（23） 式から（26）式に変更する）。ポテンシャル極大が存在 しない場合でも，H=0においてポテンシャル曲線に極 小が生じない場合および浅い場合, 不可逆凝集は起こら ないと考えられる。

\section{2 次極小を考慮した凝集}

前節までは，ポテンシャル曲線に一つの極大があり (Fig. 12)，この極大を超えると $H=0$ （1 次極小）にお いて不可逆的な凝集が起こると考えた。しかし, Fig. 12 に示したように 2 次極小が存在する場合がある。この場 合は, 2 個の単量体 $M$ (濃度 $n_{1}$ ) が 2 次極小で可逆的に 凝集し 2 量体 $S$ (濃度 $n_{2 s}$ ) を形成し, その一部が極大 を超えて不可逆的に凝集体 $P\left(\right.$ 濃度 $n_{2 \mathrm{p}}$ ) を形成すると 考えられる ${ }^{22)}$ 。

$$
2 M \underset{k_{2}}{\stackrel{k_{1}}{\longleftarrow}} \stackrel{k_{3}}{\longrightarrow} P
$$

ここで, $k_{1}, k_{2}, k_{3}$ はそれぞれ対応する速度定数である。 濃度 $n_{1}, n_{2 \mathrm{~s}}, n_{2 \mathrm{p}}$ は次式に従って時間変化する。初期条 件は $n_{1}(0)=n_{0}, n_{2 \mathrm{~S}}(0)=0, n_{2 \mathrm{P}}=0$ である。

$$
\frac{d n_{1}(t)}{d t}=-k_{1} n_{1}^{2}(t)+2 k_{2} n_{2 \mathrm{~S}}(t), \quad \frac{d n_{2 \mathrm{~S}}(t)}{d t}=\frac{1}{2} k_{1} n_{1}^{2}(t)-
$$




$$
\left(k_{2}+k_{3}\right) n_{2 \mathrm{~S}}(t), \frac{d n_{2 \mathrm{P}}(t)}{d t}=k_{3} n_{2 \mathrm{~S}}(t)
$$

これらの微分方程式に対する近似解が次のように得ら れている23)。

$$
\begin{aligned}
n_{1}(t)= & \frac{n_{0}}{2}\left\{1+\left(\frac{K_{\mathrm{a}}+K_{\mathrm{b}}-2 k_{1} n_{0}}{2 K_{\mathrm{b}}}\right) e^{-\left(K_{\mathrm{a}}-K_{\mathrm{b}}\right) t}-\right. \\
& \left.\left(\frac{K_{\mathrm{a}}-K_{\mathrm{b}}-2 k_{1} n_{0}}{2 K_{\mathrm{b}}}\right) e^{-\left(K_{\mathrm{a}}-K_{\mathrm{b}}\right) t}\right\} \\
n_{2 S}(t)= & \frac{k_{1} n_{0}^{2}}{4 K_{\mathrm{b}}}\left\{e^{-\left(K_{\mathrm{a}}-K_{\mathrm{b}}\right) t}-e^{-\left(K_{\mathrm{a}}+K_{\mathrm{b}}\right) t}\right\} \\
n_{2 P}(t)= & \frac{n_{0}}{4}\left\{1-\left(\frac{K_{\mathrm{a}}+K_{\mathrm{b}}}{2 K_{\mathrm{b}}}\right) e^{-\left(K_{\mathrm{a}}-K_{\mathrm{b}}\right) t}+\left(\frac{K_{\mathrm{a}}-K_{\mathrm{b}}}{2 K_{\mathrm{b}}}\right) e^{-\left(K_{\mathrm{a}}+K_{\mathrm{b}}\right) t}\right\}
\end{aligned}
$$

ただ， $K_{\mathrm{a}}=\left(k_{2}+k_{3}\right) / 2+k_{1} n_{0}, \quad K_{\mathrm{b}}=\left(K_{a}^{2}-2 k_{1} k_{3} n_{0}\right)^{1 / 2}$ である。Fig. 12 の内扱図に 2 次粒子の総濃度 $n_{2}(t)=n_{2 S}$ $(t)+n_{2 P}(t)$ に対する厳密解と近似解を与えたが, 両者 の一致は良い。

\section{9 おわりに}

本総説では，生体コロイド粒子のモデルとして柔らか い粒子の相互作用の問題を剛体粒子の相互作用と比較し ながら述べた。コロイド粒子分散系の相互作用以外の界 面電気現象には外部電場中でのコロイド粒子の運動（電 気泳動）等の界面動電現象がある。この問題については 文献 4, 5, 7-10) を参照されたい。

\section{文 献}

1) B. V. Derjaguin and L. Landau, Theory of stability of highly charged lyophobic sols and coalescence of highly charged particles in electrolyte solutions. Acta Physicochim USSR, 16, 633-662 (1941).

2) E. J. W. Verwey and J. Th. G. Overbeek, Theory of the Stability of Lyophobic Colloids. Elsevier, Amsterdam, 1948.

3) J. N. Israelachvili, Intermolecular and Surface Forces, Third Edition, Academic Press/Elsevier, Amsterdam, 2010 ：イスラエルアチヴィリ著 分子間力と表面力 第 3 版, 大島広行訳, 朝倉書店, 東京, 2013 .

4) H. Ohshima, Theory of Colloid and Interfacial Electric Phenomena. Elsevier/Academic Press, Amsterdam, 2006.

5) H. Ohshima, Biophysical Chemistry of Biointerfaces. John Wiley and Sons, Hoboken, 2010.

6) A. S. G. Curtis, The Cell Surface, Its Molecular Role in
Mephogenesis, Logos Press and Academic Press, London and New York, 1967.

7）大島広行, 柔らかい粒子の電気泳動と静電相互作用. 日本物理学会誌, 68, 89-97 (2013).

8) H. Ohshima, Electrokinetic phenomena of soft particles. Curr. Opin. Colloid Interf. Sc., 18, 73-82 (2013).

9) H. Ohshima, Electrostatic interaction of soft particles. Adv. Colloid Interface Sci., 226 A, 2-16 (2015).

10）大島広行, 柔らかい粒子の電気泳動と静電相互作用, 土壌と界面電気現象：基礎から土畩污染対策まで（石 黑宗秀 編集) 第 5 章, 博友社, 東京, 2015.

11) B. V. Derjaguin, Untersuchungen über die Reibung und Adhäsion, IV. Kolloid Z., 69, 155-164 (1934).

12) M. J. Sparnaay, The interaction between two cylinder shaped colloidal particles. Recueil, 78, 680-709 (1959).

13) H. Ohshima and A. Hyono, Electrostatic interaction between two cylindrical soft particles. J Colloid Interface Sci., 333, 202-208 (2009).

14) H. Ohshima and A. Hyono, The van der Waals interaction between two torus-shaped colloidal particles. $J$. Colloid Interface Sci., 332, 251-253 (2009).

15) H. Ohshima, Electrostatic repulsion between two parallel plates covered with polymer brush layers. Colloid Polym. Sci., 277, 535-540 (1999).

16) H. Ohshima, H. Electrostatic repulsion between two parallel plates covered with polyelectrolyte brush layers. Effects of interdigitation, Colloid Polym. Sci., 292, 431-439 (2014).

17) P. G. de Gennes, Polymers at interfaces; a simplified view. Adv. Colloid Interface Sci., 27, 189-209 (1987).

18) H. Ohshima, Electrostatic interaction between two interpenetrating soft particles. Colloids Surf. A: Physicochem. Engin. Aspects, 460, 448-453 (2014).

19) H. Ohshima, Interpenetration model for electrostatic interaction between two soft particles. Asian J. Phys., 23, 723-733 (2014).

20) H. Ohshima, Three-dimensional discrete charge effects on the electrostatic interaction between two soft particles. Colloid Polym. Sci., 292, 757-761 (2014).

21) H. Ohshima, Approximate analytic expression for the stability ratio of colloidal dispersions. Colloid Polym. Sci., 292, 2269-2274 (2014).

22) A. H. Behrens and M. Borkovec, Influence of the secondary interaction energy minimum on the early stages of colloidal Aaggregation. J. Colloid Interface Sci., 225, 460-465 (2000).

23) H. Ohshima, Simple analytic solution of the rate equations for the early-stage aggregation kinetics of colloidal particles, Colloid Polym. Sci., 291, 3013-3016 (2013). 